\title{
Application System for Identification of Surakarta Traditional Batik Images (SABATARA)
}

\author{
Jani Kusanti \\ Surakarta University \\ Surakarta, Indonesia \\ jani_kusanti@yahoo.com
}

\author{
Ramadhian Agus T.S. \\ Surakarta University \\ Surakarta, Indonesia \\ ramadhiantriono@yahoo.com
}

\begin{abstract}
Surakarta Batik is a traditional cloth in Indonesia that has been designated as an intangible cultural heritage by the Ministry of Education and Culture. The Surakarta Batik Pattern has characteristics and has a story in each style. The method used affects the accuracy of each pattern in the Surakarta batik image. Image data used for training data are 100 image data with a size of $256 \times 256$ pixels, with test image data used as many as 20 image data. Improving the quality of the image using contrast stretching, the output is processed to separate objects with the background using adaptive thresholding. The obtained object is added by the canny process and calculated using the Gray Level Co-Occurrence Matrix to obtain the characteristics of each image. The characteristics used are four variables (energy, contrast, homogeneity, and correlation). The resulting variable is used as input to the classification using backpropagation. The test results obtained an accuracy rate of $95 \%$, with an error rate of $0.05 \%$.
\end{abstract}

Keywords - Characteristic; Batik Patterns; Identification

\section{INTRODUCTION}

Batik patterns on the Surakarta batik image besides having characteristics also have a story on each sheet of the fabric pattern (Batik, 2015; Syahrin, 2015; Hengky, 2014). Protection of copyright needs to be done to improve the economy for batik craftsmen (Kusumaningtyas, 2009). The images obtained from the photos have different sizes with different noise levels. The equation of size and image improvement needs to be done to get better results, the method used in image improvement is contrast stretching (I Made Dwi Putra Asana, 2017; Purba, 2017; Sianturi, 2015). The improved image results are grouped and measured, the adaptive thresholding method is used to measure and get the characteristics of its image (Sinaga, 2017; Kurniawardhani, 2017). To get more optimal results, it is necessary to localize the desired object so that only the desired results are obtained (Alibeigi, 2015; Ambarwati, 2016). The measurement of results is carried out using the Gray Level Co-Occurrence Matrix (Kusanti \& Haris, 2018; Cheong, 2018; Yunari, 2018). The resulting numerical data are grouped with the aim of recognizing the object and distinguishing between the characteristics of one another (Budiman, 2017; Handhayani, 2017; Kasim \& Ahmad, 2017). The purpose of this study is to create a system that can be used to identify the original image of Surakarta batik. The benefits can be used as proof of ownership of Surakarta batik image patterns so that they are not recognized by irresponsible parties. So that it becomes important the application system for identifying traditional batik in Surakarta (SABATARA) is made to be used as a tool for identifying the traditional batik image system in Surakarta.

\section{Literature REVIEW}

In research conducted by Nurhaida, et al. (2012) compared the results of Gray Level Cooccurrence Matrices (GLCM) with Canny Edge Detection and Gabor filters to recognize batik images, the results of research obtained by GLCM are the best feature extraction methods to recognize Batik images. Minarno, et al. (2014) combines the GLCM feature extraction method with Discrete Wavelet Transform (DWT), which is named Co-Occurrence Matrices of Sub-Band Image to classify the basic motifs of Batik, 
where in one class of basic motifs of Batik, there are various ways to describe their basic motifs. In the research conducted by Kusanti (2018) in his research using 4-level Gray Level Co-occurrence Matrices (GLCM) for feature extraction that can be used to recognize the literature review image of no more than 1000 words by expressing the state of the art in the field of study. Chart can be made in the form of JPG / PNG which is then inserted in this field. Primary sources of literature / references that are relevant and prioritizing research results in the latest scientific journals and / or patents. It is recommended to use library resources in the last 10 years. with $80 \%$ validation results. Then, Guo (2010) in his research proposes the Completed Local Binary Pattern (CLBP) method to correct LBP's weaknesses that are less accurate in describing the local structure of the image. Several different local image structures can have the same LBP value. Guo added the feature of the difference magnitude value between the central pixel and neighboring pixel (CLBP_M) and the characteristic of the central pixel to the overall image intensity value (CLBP_C), to complement the characteristic sign value of the difference between the central pixel and neighboring pixel (CLBP_S). CLBP_S is the same as LBP. In that study, Guo stated that CLBP_M performance is better than the VAR feature in describing the value of local variance, because VAR only describes the value of variance of local intensity by ignoring the local spatial structure. On the other hand, Zhao (2013) proposed Completed Robust Local Binary Pattern (CRLBP). CRLBP is also a method based on LBP. CRLBP is proposed to improve Completed Local Binary Pattern (CLBP), which is sensitive to noise. If there is noise, especially at the center of the central pixel it can affect the LBP value. CRLBP also consists of 3 features such as CLBP, namely CRLBP_S, CRLBP_M, and CRLBP_C. The difference between CLBP and CRLBP is the thresholding value. CRLBP does not directly use the central intensity value as the thresholding value, which will later be used as a comparison with the neighbor intensity value. The CRLBP_M feature also describes the value of the local intensity variant. CRLBP_M is expected to be better than CLBP_M, because it is not sensitive to noise. In this study will use the method of contrast stretch (Contrast stretching), Histogram equalization, Low pass filter, Gaussian filter in image improvement. From the results of image improvement, the ROI (Region of Interest) results from ROI followed by segmentation using two segmentation methods consisting of otsu thresholding and adaptive thresholding. After the segmentation process the results obtained are followed by a mathematical calculation process carried out using canny edge detection and hole filling. The final calculation result is used by GLCM to identify the authenticity of the Surakarta Batik image.

\section{Proposed Method}

The method used in this study is shown in Error! Reference source not found.

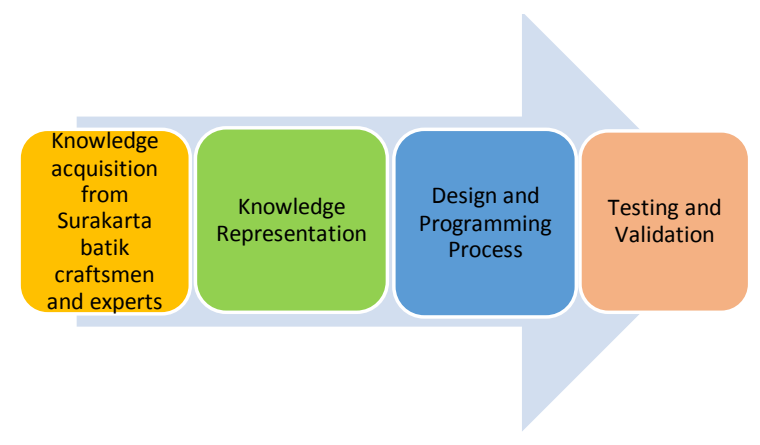

Fig. 1.Research methods

Knowledge Acquisition

Knowledge acquisition is carried out by observing, namely coming directly to the location of batik craftsmen in the Surakarta region, namely in Laweyan and Brotojoyo batik home industry, shown in Error! Reference source not found.

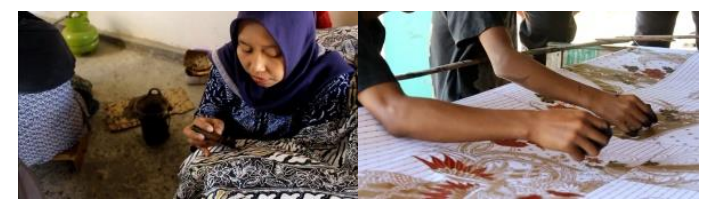

Fig. 2. Knowledge acquisition to the location of Surakarta and Sragen batik craftsmen

The purpose of observation to several craftsmen for a direct interview about any problems that occur in the field, the decline in prices of original batik in Surakarta due to the number of imitation batik patterns that are almost similar to the original style of batik in Surakarta. Special characteristics of Surakarta batik pattern and the meaning of each style. For this reason it is important to make the SABATARA application system. Here are 7 shades of the original image of Surakarta, shown in Fig. 3 


\section{Sin Journal Publications \& Informatics Engineering Research

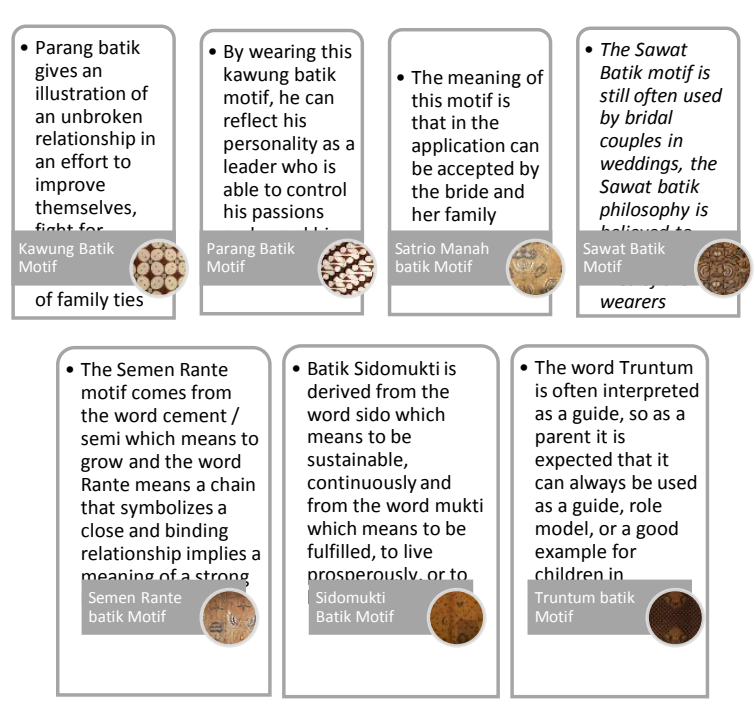

Fig. 3. Pattern of Surakarta traditional batik image

Knowledge representation

Knowledge representation uses the stages of collecting image data in the form of images from Surakarta batik images. The batik image used in the study was divided into 100 training data images and 20 test data images. An example of the image used is shown in Fig. 4

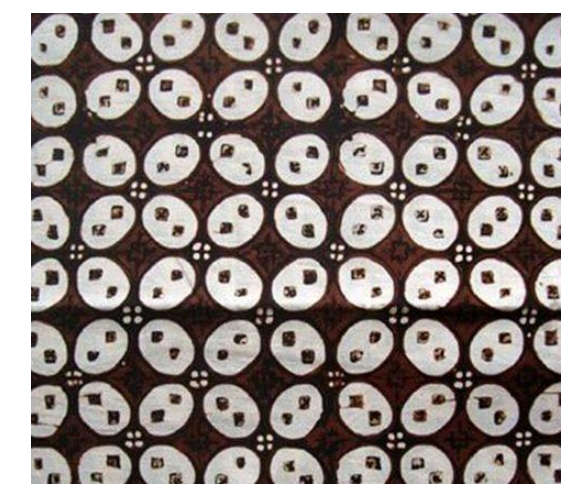

Fig. 4.Example of batik image

Design and Programming Process

The design of the Surakarta traditional batik (SABATARA) application programming system created is shown in 0

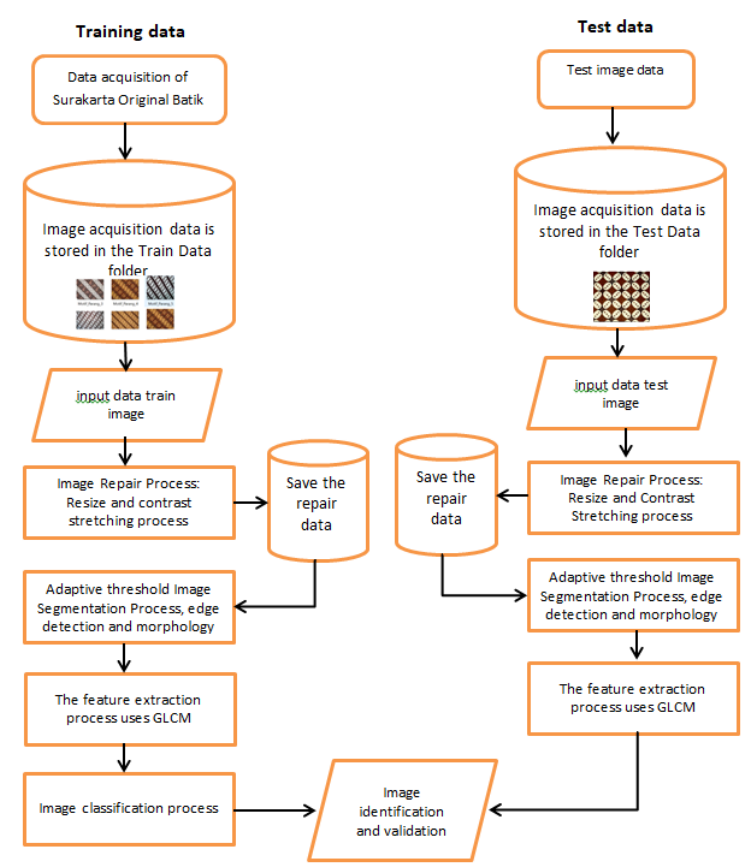

Fig. 5.Design and Programming Process

Process 1: The input image is resized to $256 \times 256$ pixels, the goal of the image being the same size during processing.

Process 2: The resized image is processed to improve its image using contrast stretching.

Contrast Stretching Algorithm:

- Input batik image in the image data folder

- Change the RGB image to Grayscale

- Look for grayscale values with the smallest to largest gray values from $0-255$ to find the first pixel value whose threshold value exceeds the first threshold specification value

- Look for a grayscale value with the largest to smallest gray value from $0-255$ to find the first pixel value which is the threshold value smaller than the second threshold specification value

- Pixels that are between the first and second threshold values are scaled to meet the complete range of gray values between 0-255 by entering the desired grayscale value. The higher the grayscale value in the image, the improved image quality will have a higher and better contrast value.

Process 3: After the image is corrected, a segmentation process is carried out. This process is 
carried out with three methods, namely adaptive thresholding, edge detection, and morphology. The formulation of the adaptive thresholding or otsu method is as follows, the threshold value to be searched for from a graylevel image is stated $\mathrm{k}$. The value of $k$ ranges from 1 to $L$, with a value of $L=255$. The probability of each pixel at level i can be expressed by the equation 1 .

$$
g(x, y)=\left\{\begin{array}{l}
0 f(x, y)<T \\
1 f(x, y) \geq T
\end{array}\right\}
$$

The aim of the Otsu method is to find a threshold point that divides the gray level image histogram into two different regions automatically, where the chosen point is such that the interclass variance is as large as possible. This goal is achieved by minimizing the weights within class variance, which actually is the same as: maximizing inter-class variance. Equation 2 displays the weight formula of within class variance.

$$
\sigma_{w}^{2}(t)=q_{1}(t) \sigma_{1}^{2}(t)+q_{2}(t) \sigma_{2}^{2}(\mathrm{t})
$$

With : $\sigma_{w}^{2}(t)$ : total within class variance, $\sigma_{1}^{2}(t)$ : within class variance of the first class, $\sigma_{2}^{2}(t)$ : within class variance of the second class, $q_{1}(t)$ : class probabilities of first class, $q_{2}(t)$ : class probabilities of the second class, $t$ : gray level value that is the threshold value. Class probabilities of the first and second classes are (where i represents the number of occurrence of pixels for gray level). Within class variance of each class is shown in equation 3 and equation 4

$$
\begin{aligned}
& \sigma_{1}^{2}(t)=\sum_{i=1}^{t}\left[i-\mu_{1}(t)\right]^{2} \frac{P(i)}{q_{1}(t)} \\
& \sigma_{1}^{2}(t)=\sum_{i=1}^{t}\left[i-\mu_{1}(t)\right]^{2} \frac{P(i)}{q_{1}(t)}
\end{aligned}
$$

After calculating the values of $\sigma_{1}^{2}(t)$ and $\sigma_{2}^{2}(t)$ on the grayscale image, a minimum within class variance value is obtained. The value of that makes $\sigma_{1}^{2}(t)$ and $\sigma_{2}^{2}(t)$ to be the minimum is the threshold value sought. The total variance value in the image is always constant, independent of the threshold value. For any threshold $\mathrm{t}$, total variance $=$ the sum of within class variance and inter class variance, obtained by the equation 5 .

$\sigma^{2}=\sigma_{w}^{2}(t)+q_{1}(t)[1-1(t)]\left[\mu_{-} 1\left(t-\mu_{-} 2(t)\right)\right]^{2}$

Process 4: The next process is a morphological process that is a process of dilation and erosion. Dilation is a morphological operation that will add pixels to the boundary between objects in a digital image. This operation uses the following rules: "For grayscale images, the value of the operation result (output pixel) is the maximum value obtained from the neighboring pixel set. In binary images, if there is a neighboring pixel that has a value of 1 then the output pixel will be set to $1 "$. Erosion is a morphological operation that will reduce pixels at the boundary between objects in a digital image. This operation uses the following rules: "For grayscale images, the value of the operation result (pixel output) is the minimum value obtained from the set of neighboring pixels. In binary images, if there is a neighboring pixel that has a value of 0 then the output pixel will be set to $0 "$.

Process 5: After a morphological process, the next step is the feature extraction process using the GLCM (Gray-Level Co-Occurrence Matrix) method using 4 features, namely contrast, correlation, energy, and homogeneity. The 4 th result is the characteristics of the 4 angles viz $0^{0}, 45^{\circ}, 90^{\circ}$ and $135^{\circ}$ these are averaged and the results are used to differentiate between features. Kookurensi means joint events, i.e., several occurrences of one level of neighboring pixel value with another level of the pixel value in the distance (d) and angular orientation $(\theta)$ certain. Distance is expressed in pixels and orientation is expressed in degrees. The orientation is formed in four angular directions with angular intervals $45^{\circ}$, that is $0^{\circ}, 45^{\circ}, 90^{\circ}$, and $135^{\circ}$. The distance between pixels is set at 1 pixel. The cohesion matrix is a square matrix with as many elements as the square of the number of pixel intensity levels in the image. Each point $(p, q)$ on the orientation matrix is oriented $\theta$ contains the probability of occurrence of $p$-value pixels next to a pixel of value $\mathrm{q}$ at distanced and orientation $\theta$ and $(180-\theta)$. Can be seen Error! Reference source not found. hat the sum of the values from column 1 and column 2 and so on are entered into the cohesion matrix according to rows and columns.

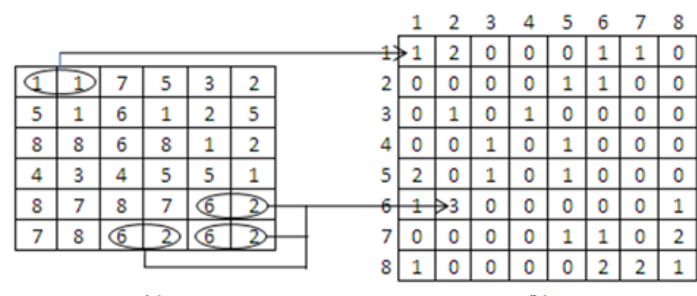

(a)

(b)

Fig. 6. Co Occurrence matrix (a) original image (b) co occurrence matrix

The features used in this study are energy, correlation, homogeneity and contrast.

Equation 6 shows the energy formula used,

$\sum_{i=1}^{K} \sum_{j=1}^{K} p_{i^{2} j}$

Where :

$\mathrm{i}=$ row, $\mathrm{j}=$ coulumn, $\Sigma=$ sum, 
$p(i, j)=$ represents the values in row $i$ and column $\mathrm{j}$ in a cohesion matrix.

The more homogeneous an image, the greater the energy value.

Equation 7 shows the contrast formula,

$$
\sum_{i=1}^{K} \sum_{j=1}^{K}(i-j)^{2} p_{i j}
$$

Contrast is used to measure the spatial frequency of an image and the difference in height and height of a pixel. Contrast will be 0 if the neighboring pixels have the same value.

Equation 8: The homogeneity formula will be of high value when all pixels have the same or uniform values. The opposite of contrast is that it will be of great value if it has the same pixel value when the energy is of fixed value.

$$
\sum_{i=1}^{K} \sum_{j=1}^{K} \frac{p_{i j}}{1+|i-j|}
$$

Equation 9: Correlation is used to measure linearity (the joint probability) of a number of pixel pairs.

$$
\sum_{i=1}^{K} \sum_{j=1}^{K} \frac{\left(i-m_{r}\right)\left(j-m_{c}\right) p_{i j}}{\sigma_{r} \sigma_{c}}
$$

Where : $\sigma_{r} \neq 0 ; \sigma_{c} \neq 0$

$P(i, j)$ is the $i$-th row element, the j-column of the normalized cohesion matrix.

$m_{r}=$ normalized row values

$m_{c}=$ column average value

$\sigma_{r}$ and $\sigma_{c}=$ Standard deviations are calculated by rows and columns, respectively

Process 6: After obtaining a value in the image characteristics such as energy, contrast, homogeneity and correlation, the value is used as an input value in the classification process using backpropagation. The calculation process with a hidden layer, to recognize the XOR logic function with 4 inputs X1, X2, X3, X4 and $\mathrm{t}=0$.

Process 7: The testing and validation process is carried out using the formula in equation 10

$$
\text { Accuracy }=\frac{n_{b}}{N} \times 100 \%
$$

Where $n_{b}$ is the amount of test data grouped appropriately and $\mathrm{N}$ is the amount of test data.

\section{RESUlt AND Discussion}

The results of the process at the beginning of the image in the form of batik image data are as follows, shown in Fig. 7

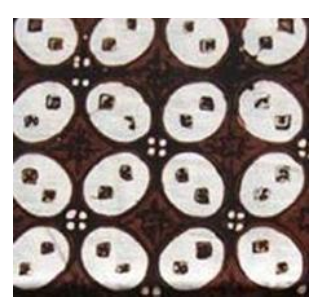

Fig. 7. Original data of batik image

The data is processed using contrast stretching the results shown in Error! Reference source not found.

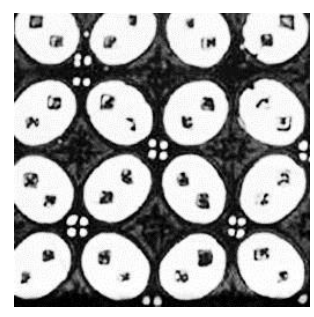

Fig. 8. Data on contrast stretching results

The results of contrast stretching are processed using adaptive threshold (otsu) and continued with the morphological process the results are shown Fig. 9

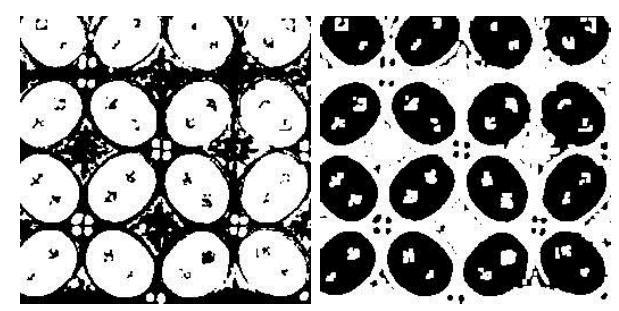

Fig. 9. The data from the adaptive threshold were followed by the morphology process

After the binary value is obtained, a calculation will be performed to obtain the characteristics of each image using GLCM. As shown in Fig. 10

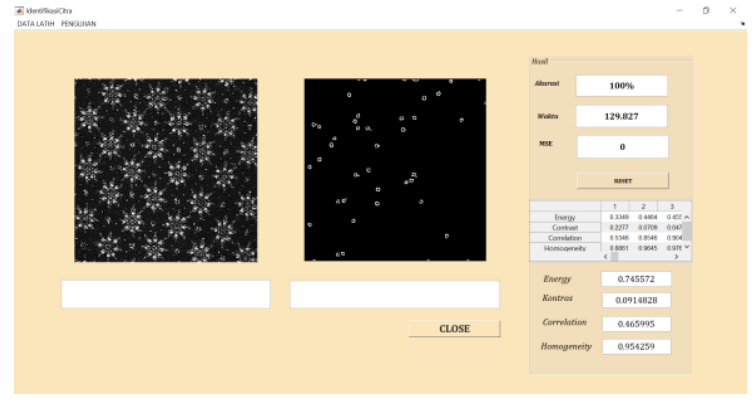

Fig. 10. SABATARA Process 
Data results are shown in TABLE I.

TABLE I. CALCULATION PROCESS RESULT OF GLCM

\begin{tabular}{|l|r|r|r|r|}
\hline \multicolumn{1}{|c|}{ Image Name } & \multicolumn{1}{|c|}{ Energy } & Contrast & Correlation & Homogeneity \\
\hline Kawung Motif & 0,455 & 0,048 & 0,904 & 0,976 \\
\hline Parang Motif & 0,492 & 0,038 & 0,919 & 0,981 \\
\hline Satrio Manah Moti & 0,300 & 0,376 & 0,194 & 0,812 \\
\hline Sawat Motif & 0,322 & 0,252 & 0,485 & 0,874 \\
\hline Semen Rante Moti & 0,715 & 0,113 & 0,386 & 0,943 \\
\hline Sidomukti Motif & 0,296 & 0,349 & 0,268 & 0,826 \\
\hline Truntum Motif & 0,670 & 0,071 & 0,733 & 0,965 \\
\hline
\end{tabular}

After the GLCM calculation process, the data is carried out the Train process for classification using backpropagation. The results are shown in Fig. 11

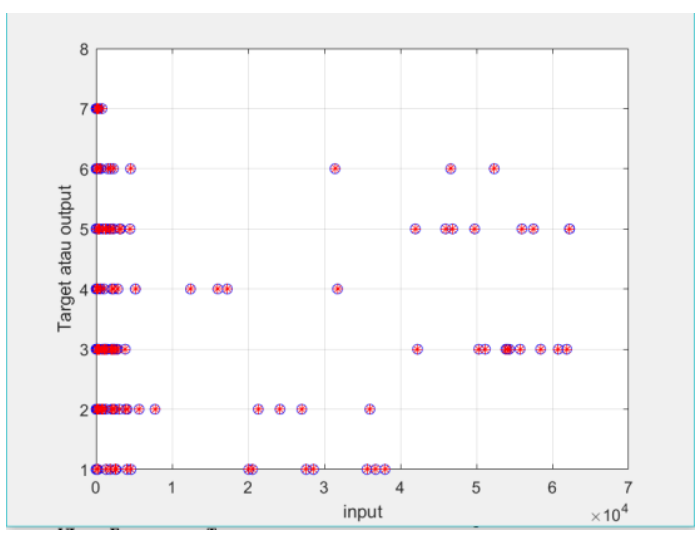

Fig. 11. The results of image classification are grouped in 7 classes

Fig. 12. With an accuracy rate of $100 \%$ for 100 training data and a mean square error value of 0 , can be seen in Fig. 13

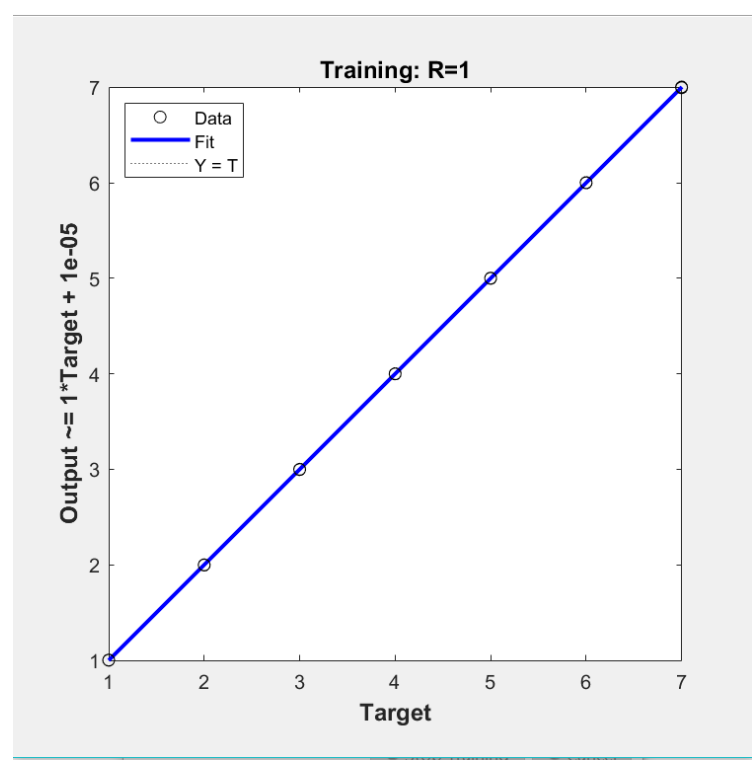

Fig. 13. Training data test results

For testing data, from 20 test data, 19 true and 1 incorrect data were obtained with an accuracy rate of $93 \%$.

\section{Conclusion And Suggestion}

The results obtained from the SABATARA system can be implemented with an accuracy rate of 93\% and an MSE level of $0.05 \%$ so that it can be concluded that the SABATARA system can be used to help identify the original image of Surakarta batik.

Suggestions for further research on the development of each home industry database is important so that each home industry ownership of the design image can be identified by the owner.

\section{REFERENCES}

Alibeigi, M. (2015). A Robust Statistical Color Edge Detection for Noisy Images. SemanticScholar.

Ambarwati, A. P. (2016). Segmentasi Citra Digital Menggunakan Thresholding Otsu untuk Analisa Perbandingan Deteksi Tepi. Annual Research Seminar 2016, (p. 216).

Batik, S. (2015). Batik Fabric Atlanta with Special Cotton and Original Handmade. 2-5.

Bayu L.A.A., B. C. (2016). Makalah Budaya Nusantara Batik Vorstenlanden. Telkom University.

Brasilka, Y. (2015). KLASIFIKASI CITRA BATIK BESUREK 
JARINGAN SYARAF TIRUAN SELF ORGANIZING MAP ( SOM ). Jurnal Rekursif, 132-145.

Budiman, F. (2017). Determination of SVM-RBF kernel space parameter to optimize accuracy value of Indonesian Batik images classification. ournal of Computer Science.

Cheong, M. (2018). Textile Recognition Using Tchebichef Moments of Co-occurrence Matrices Textile Recognition Using Tchebichef Moments of Co-occurrence Matrices.

Handhayani, T. (2017). Comparison of Shallow and Deep Learning Models for Classification of Lasem Batik Patterns. roceedings - 2017 1st International Conference on Informatics and Computational Sciences, ICICoS 2017.

Hashem, H. F. (2009). Adaptive technique for human face detection using HSV color space and neural networks. National Radio Science Conference. IEEE.

Hengky, S. (2014). Image Analysys: Performance Gaps of Batik Craft in Yogyakarta, Indonesia. Macrothink Institute, Business Management and Strategy, 127-138.

I Made Dwi Putra Asana, I. M. (2017). Metode Contrast Stretching untuk Perbaikan Kualitas Citra Pada Proses Segmentasi Video. Teknologi Elektro, 1-6.

Ida Nurhaida, H. W. (2016). Texture fusion for batik motif retrieval system. International Journal of Electrical and Computer Engineering (IJECE) , 3174-3187.

Kasim, \& Ahmad, A. (2017). Batik Classification with Artificial Neural Network Based on Texture-Shape Feature of Main Ornament. International Journal of Intelligent Systems and Applications, 55-65.

Kurniawardhani, A. (2017). Efficient texture image retrieval of improved completed robust local binary pattern. International Conference on Advanced Computer Science and Information Systems, ICACSIS 2016.

Kusanti, J., \& Haris, N. A. (2018). Klasifikasi Penyakit Daun Padi Berdasarkan Hasil Ekstraksi Fitur GLCM Interval 4 Sudut. urnal Teknologi Informasi dan Komunikasi (JTIK), 1-6.

Kusumaningtyas, R. F. (2009). Perlindungan Hak Cipta Atas Motif Batik Sebagai Warisan Budaya Bangsa ( Studi Terhadap Karya Seni Batik Tradisional Kraton Surakarta).

Meccasia, K. (2015). Klasifikasi Motif Batik Banyuwangi Menggunakan Metode
Ekstraksi Ciri Wavelet Dan Metode Klasifikasi Fuzzy Logic. e-Proceeding of Engineering, (pp. 2760-2766).

Minarno, A. E. (2016). Batik Image Retrieval Based on Enhanced Micro-Structure Descriptor. 2014 Asia-Pacific Conference on Computer Aided System Engineering, APCASE 2014.

O'Rourke, J. (2017). Handbook of Discrete and Computational Geometry, Third Edition.

Padmo A.M, A. (2016). Segmentasi Citra Batik Berdasarkan Fitur Tekstur Menggunakan Metode Filter Gabor Dan K-Means Clustering. Jurnal Informatika.

Pittsburgh, U. o. (2019, February 18). University of Library System. Retrieved from Citation Styles: APA, MLA, Chicago, Turabian, IEEE: APA 6th Edition: https://pitt.libguides.com/c.php?g=12108\& $\mathrm{p}=64730$

Purba, B. (2017). Aplikasi Perbaikan Kualitas Citra Hasil Penginderaan Jauh (Remote Sensing) Dengan Metode Contrast Stretching. Jurnal Times (Technology Informatics \& Computer System), 26-36.

R, I. D. (2016). Klasifikasi Batik Menggunakan KNN Berbasis Wavelet . Seminar Nasional Teknologi Informasi dan Komunikasi 2016 (SENTIKA 2016) (2016) Yogyakarta.

Rahayuda, I. G. (2015). Texture Analysis on Image Motif of Endek Bali using K-Nearest Neighbor Classification Method. International Journal of Advanced Computer Science and Applications, 205211.

Rangkuti, A. H. (2015). Batik image classification using treeval and treefit as decision tree function in optimizing content based batik image retrieval. Procedia Computer Science, (pp. 577-583).

Sari, Y. (2018). Classification of Coastal and Inland Batik using GLCM and Canberra Distance. AIP Conference Proceedings.

Sari, Y. (2018). Klasifikasi Pengenalan Motif Batik Berbasis Image Retrieval. Jukung Jurnal Teknik Lingkungan, 27-33.

Sianturi, F. A. (2015). Penerapan Metode Contrast Stretching Untuk Peningkatan Kualitas Citra Bidang Biomedis. Jurnal Matik Penusa (Jurnal Manajemen dan Informatika Pelita Nusantara), 42-47.

Sinaga, A. S. (2017). Implementasi Teknik Thresholding Pada Segmentasi Citra Digital. Jurnal Mantik Penusa (Jurnal 
Manajemen Dan Informatika Pelita Nusantara), 48-51.

Syahrin, A. (2015). The Batik Motif.

WHO. (2004). Developing health management information systems: a practical guide for developing countries. Dev. Heal. Manag. Inf. Syst. a Pract. Guid. Dev. Ctries., 60.

Wicaksono, A. Y. (2017). Modified Convolutional Neural Network Architecture for Batik Motif Image Classification. IPTEK Journal of Science, 26-30.
Yohanes Gultom, R. J. (2018). Batik Classification Using Deep Convolutional Network Transfer Learning. Jurnal Ilmu Komputer dan Informasi (Journal of a Science and Information), 59-66.

Yunari, N. (2018). Extraction Gray Level Cooccurrence Matrix ( GLCM ) and Learning Vector Quantization ( LVQ ). Journal of Telecommunication, Electronic and Computer Engineering, 67-71. 